\title{
2014年12月に北海道で発生した温帯低気圧によ る根室の高潮被害の現地調査と発生機構の解明
}

\author{
中村 亮太 1 - 岩本 匠夢 1 柴山 知也 2 三上 貴仁 3 ・ \\ 松葉 俊哉 4 ・Martin MAELL 5 ・舘小路 晃史 1 ・田野倉 祐介 6 \\ 1 学生会員 早稲田大学大学院 創造理工学研究科（干169-8555 東京都新宿区大久保 3-4-1) \\ E-mail: ryota_nakamura617@yahoo.co.jp \\ 2 フェロー会員 早稲田大学教授 理工学術院（干169-8555 東京都新宿区大久保 3-4-1) \\ 3 正会員 早稲田大学講師 理工学術院（干169-8555 東京都新宿区大久保 3-4-1) \\ 4 国土交通省＼cjkstart東北地方整備局北上川下流事務所（干986-0861 宮城県石巻市蛇田新下沼 80） \\ 5 早稲田大学大学院 創造理工学研究科（干169-8555 東京都新宿区大久保 3-4-1) \\ 6 東京工業大学大学院 情報理工学研究科情報環境学専攻（†152-8550 東京都目黒区大岡山 2 丁目 12-1）
}

\begin{abstract}
2014 年 12 月中旬に発生した温帯低気圧は急速に発達し，根室に高潮被害をもたらした。本研究では, 根室に生じた高潮の現地調查の結果を整理し, 数值モデルを用いて高潮の再現を試みた. 現地調査の結果, 根室市街地の浸水高は最大で $2.20 \mathrm{~m}$ であった。一方，根室港では最大の $2.82 \mathrm{~m}$ を記録した. 現地調査の結 果，地盤高が海岸線から市街地に向けて徐々に低下していた。この地形的特性が根室市弥生町市街地に高 潮被害をもたらした原因の一つである. 数值計算の結果, 根室湾で水位が上昇・下降する現象が見られた. 具体的には，まず東風が吹き，根室湾の水位が上昇する．次に，風向きが北風に変化して，根室湾に溜ま った水塊が根室半島に吹き寄せられ，根室港での高潮偏差が増加するという結果を得た。根室市街地の地 形的特性, 風向きの変化と根室湾と根室半島の相対的位置関係などの条件が高潮被害をもたらした.
\end{abstract}

Key Words : low pressure system, storm surge, field survey, Nemuro, inundation, WRF, FVCOM

\section{1. 序論}

近年，世界各地で台風による高潮被害が頻発している. 例示すれば，2013年に発生した台風Haiyanは，フィリピ ンのレイテ島一帯に高潮被害をもたらした。 また，地球 温暖化に伴う台風の強大化により高潮被害の増加も予測 されている1)。そこで，台風による高潮災害を詳細に算 定可能な気象・海洋数值モデルの検証が行われてきた(例 えば，吉野ら ${ }^{2)}$ )。一方で，急速発達する温帯低気圧に伴 う海洋現象の研究では，森ら 3 による暴波浪特性に関す る研究が行われているが，高潮の研究例は少ない．これ は，急速発達する低気圧による高潮の被災件数が過去に 例が少ないためと考えられる. そのため，急速発達する 低気圧による高潮という特別な事例を詳細に分析し，災 害素因を評価することは，沿岸付近の防災力向上に必要 であると考えた.

2014年12月16日から17日にかけて急速に発達した低 気圧は，根室港および根室の市街地に高潮被害をもたら した. 2014年から2015年の冬季は，中心示度が980hPaを 下回る低気圧が北海道の付近を通過するという気象現象 が例年より多く見受けられた ${ }^{4)}$. 今後もこの傾向が継続 する場合には，同様の発生機構を有した高潮が生じる可
能性が高まると考えられる.

本論文では，(1)発生した低気圧の特性の分析，(2)高潮 被災の現地調査, (3)数值モデルによる検討，の3段階の検 証を行い，根室に高潮を引き起こした低気圧及び高潮の 物理特性を解明し, 高潮の発生機構の評価を試みる。

\section{2014 年 12 月に発生した低気圧の特性}

2014年12月 16日12時に日本海中部と四国の南部の海 面更正気圧が992 hPa と $1002 \mathrm{hPa}$ の低気圧は，ともに北東 に進み, 17日の9時に北海道東部の海上で $948 \mathrm{hPa}$ 勢力を もつ低気圧へと急速発達した ${ }^{5), 6)}$. 最大風速は，根室市納 沙布で30.7 m/s, 最大瞬間風速は, 根室市弥栄町で $39.9 \mathrm{~m} / \mathrm{s}$ であった ${ }^{5)}$. 根室では，低気圧の接近により，17日午前 に潮位がTP+1.7 1.9 mとなった ${ }^{7)}$ とこれにより, 高潮に よる住居の床上・床下浸水が発生した ${ }^{5)}$.

図-1は，12月17日9時の気象庁速報天気図である6). 急 速発達した低気圧が北海道東部海上に存在している。ま た，図-2の12月18日6時の気象庁速報天気図 ${ }^{(6)}$ をみると， 発達した低気圧は約1日間, 北海道の東部海上に留まって いた。 中心気圧の值は，日本に襲来する台風と同程度で 


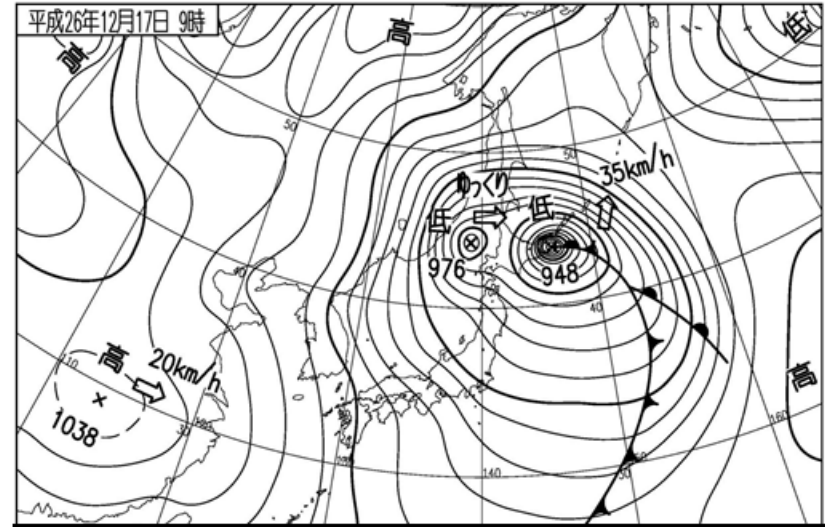

図-1 気象庁速報天気図の一部抜粋 ${ }^{6}$

(12月 17 日の午前 9 時)

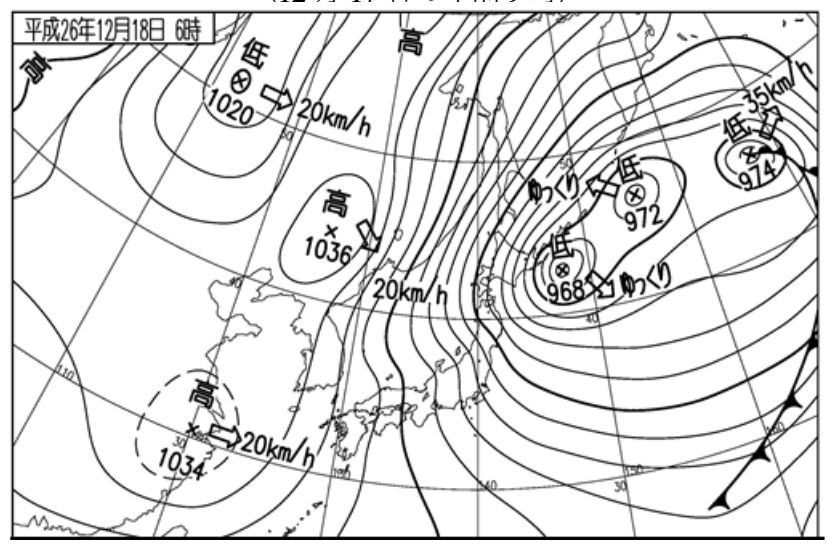

図-2 気象庁速報天気図の一部抜粋 6)

(12月 18 日の午前 6 時)

あり，台風の勢力と同等の勢力をこの温帯低気圧は有し ていたといえる．更に，等圧線が台風の等圧線のように 同心円に近いという特性も有していた（図-1）.

\section{3. 現地調査結果}

現地調査は2014年12月19日に実施した。高潮発生2日 後であるため, 高潮浸水の痕跡がはっきりと残っていた. 表-1に高潮痕跡高の諸情報を示す. 11地点で調査を行っ た. ここで，浸水高は高潮来襲時の天文潮位からの痕跡 高であり，遡上高は海岸から内陸へ高潮が駆け上がる際 の到達点の高さである. 本論文では，17日午前9時の天文 潮位を使用している。図-3は，根室市弥生町市街地の測 定点の分布である. 市街地での最大浸水高は, 地点 $\mathrm{D} の$ 2.20 mであった. 海岸線から弥生町交差点の付近にかけ て，地盤高が低下している（表-1）。海岸線の地盤高を 高潮が超えると内陸に浸水しやすい地形をしていたこと を示している. 弥生町交差点付近の地形特性も高潮浸水 域が拡大した一因である. 図-4は根室港付近の測定点の 位置である，根室港では，市街地と比較して浸水高が全 体的に高かった. 根室港では, 地点Kで $1.80 \mathrm{~m}$ を計測し, より湾奥の地点Jでは， $2.82 \mathrm{~m}$ を記録した. この現地調

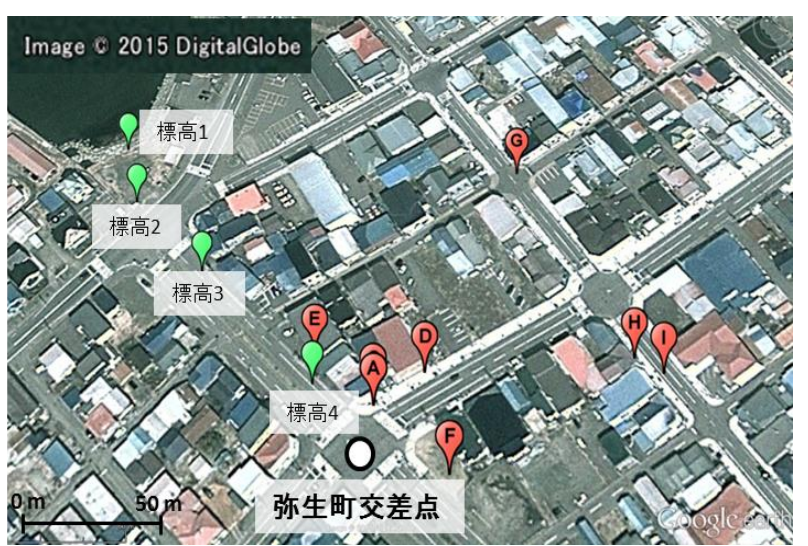

図-3 根室市弥生町交差点付近の測定位置

(Google Earth に加筆)

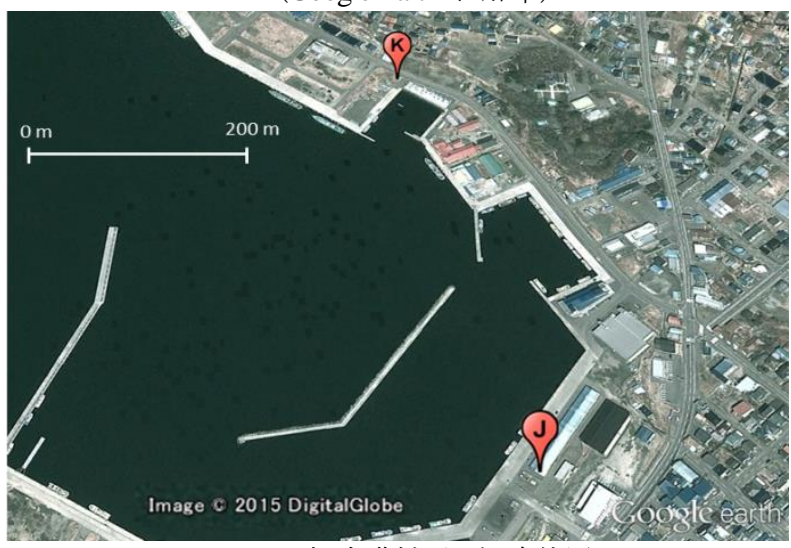

図-4 根室港付近の測定位置

(Google Earth に加筆)

查の結果から，港湾のような狭い範囲内でも，港奥は高 潮が高くなっていた．港奥では，急に水深が減少してお り，なおかつ港奥は境界があり水が溜まりやすいため, 港奥での高潮偏差が上昇したと考えらえる. $2.80 \mathrm{~m}$ の浸 水高さを記録した根室港にある地点 $\mathrm{J}$ においても，家屋 の破壊は見られなかった。今回の低気圧によって引き起 こされた高潮は, 2013 年にフィリピンで発生した高潮と 異なり，段波を伴わない，徐々に海面が上昇する高潮で あったため, 高潮前面での衝撃波圧が大きくなく, 構造 物に物理的な被害を及ぼさなかったと考えられる.

表-1 高潮痕跡高 (地盤高は TP+ 表示)

\begin{tabular}{|c|c|c|c|c|c|c|}
\hline 定地点 & 緯度 & 経度 & 地盤高 $(m)$ & 高さ $(m$ & 種別 & 根拠 \\
\hline A & $43^{\circ} 19^{\prime} 57.90^{\prime \prime}$ & $145^{\circ} 34^{\prime} 42.54^{\prime \prime}$ & $T P+0.83$ & 1.66 & 浸水高 & 痕跡 \\
\hline $\mathrm{B}$ & $43^{\circ} 19^{\prime} 57.90^{\prime \prime}$ & $145^{\circ} 34^{\prime} 42.54^{\prime \prime}$ & $T P+0.83$ & 1.59 & 浸水高 & 痕跡 \\
\hline C & $43^{\circ} 19^{\prime} 57.90^{\prime \prime}$ & $145^{\circ} 34^{\prime} 42.54^{\prime \prime}$ & $\mathrm{TP}+0.83$ & 1.56 & 浸水高 & 痕跡 \\
\hline$D$ & $43^{\circ} 19^{\prime} 58.26^{\prime \prime}$ & $145^{\circ} 34^{\prime} 43.32^{\prime \prime}$ & $\mathrm{TP}+1.24$ & 2.20 & 浸水高 & 住民の証言 \\
\hline$E$ & $43^{\circ} 19^{\prime} 58.27^{\prime \prime}$ & $145^{\circ} 34^{\prime} 41.45^{\prime \prime}$ & $T P+0.70$ & 1.39 & 浸水高 & 痕跡 \\
\hline $\bar{F}$ & $43^{\circ} 19^{\prime} 57.06^{\prime \prime}$ & $145^{\circ} 34^{\prime} 43.58^{\prime \prime}$ & $T P+1.71$ & 1.41 & 遡上高 & 雪が溶けている \\
\hline$G$ & $43^{\circ} 20^{\prime} 00.94^{\prime \prime}$ & $145^{\circ} 34^{\prime} 45.41^{\prime \prime}$ & $\mathrm{TP}+1.84$ & 2.16 & 浸水高 & 住民の証言 \\
\hline $\mathrm{H}$ & $43^{\circ} 19^{\prime} 58.30^{\prime \prime}$ & $145^{\circ} 34^{\prime} 46.95^{\prime \prime}$ & $T P+1.52$ & 1.74 & 浸水高 & 住民の証言 \\
\hline I & $43^{\circ} 19^{\prime} 58.10^{\prime \prime}$ & $145^{\circ} 34^{\prime} 47.40^{\prime \prime}$ & $\mathrm{TP}+1.47$ & 1.55 & 浸水高 & 住民の証言 \\
\hline $\mathrm{J}$ & $43^{\circ} 20^{\prime} 21.72^{\prime \prime}$ & $145^{\circ} 35^{\prime} 06.78^{\prime \prime}$ & $T P+2.07$ & 2.82 & 浸水高 & 住民による写真 \\
\hline $\mathrm{K}$ & $43^{\circ} 20^{\prime} 38.16^{\prime \prime}$ & $145^{\circ} 35^{\prime} 06.78^{\prime \prime}$ & $\mathrm{TP}+1.89$ & 1.80 & 浸水高 & 住民による写真 \\
\hline 標高1 & $43^{\circ} 20^{\prime} 01.69^{\prime \prime}$ & $145^{\circ} 34^{\prime} 37.82^{\prime \prime}$ & $T P+1.56$ & - & 地盤高 & - \\
\hline 標高2 & $43^{\circ} 20^{\prime} 00.84^{\prime \prime}$ & $145^{\circ} 34^{\prime} 38.10^{\prime \prime}$ & $T P+1.40$ & - & 地盤高 & - \\
\hline 標高3 & $43^{\circ} 19^{\prime} 59.76^{\prime \prime}$ & $145^{\circ} 34^{\prime} 39.42^{\prime \prime}$ & $T P+1.20$ & - & 地盤高 & - \\
\hline 標高4 & $43^{\circ} 19^{\prime} 58.20^{\prime \prime}$ & $145^{\circ} 34^{\prime} 41.40^{\prime \prime}$ & $\mathrm{TP}+0.79$ & - & 地盤高 & - \\
\hline
\end{tabular}




\section{4. 算定手法の概要}

算定手法は，中村ら ${ }^{8)}$ が台風 Yolanda（2013）に使用し た手法と同様に, 気象モデルにはARW-WRF'泉を使用し， 海洋モデルには $\mathrm{FVCOM}^{10)}$ を使用した．各モデルの詳細 な計算条件の設定を表-2 に示す.

\section{1) 気象モデルのWRF の設定}

本研究では，WRFに $\mathrm{FNL}^{11)}$ ， GFS ${ }^{12)}$ を用いた標準的な 手法と TC ボーガス ${ }^{13)} \mathrm{WRF}$ の計算結果として逐次的 に埋め込み，気象場を決定した手法を用いて，低気圧を 再現した. FNL と GFS の初期気象場が計算結果に与え る影響を考慮して，開始時間を 2 ケース設定した．FNL を用いた，計算開始時間が 16 日 21 時，17日 3 時のケー ス名をそれぞれ，fnl-1，fnl-2 とした. GFS を用いたケー ス名も同様に設定した. TC ボーガスを用いたケースで は，最大風速半径を $60 ， 70,80,90,100 \mathrm{~km}$ と設定し た. ケース名は, 先頭に TC と最大風速半径の值で示し ている. 以上の合計 9 ケースの計算を行った. TC ボー ガスは，同心円形の気象場を再構成する手法である. 発 生した低気圧の中心付近の海面更正気圧が同心円状に広 がっていたことを考慮すると，発生した低気圧は台風の 形状に近い. 気圧分布の対称性という観点からは TC ボ 一ガスの利用も許容できると考えた． TC ボーガスを用 いた計算は，気象庁が発表した速報天気困から海面更正 気圧とその中心位置を決定し， Atkinson・Holliday ${ }^{16)}$ が 提案した以下の式（1）を用いて，最大風速を決定した。

$$
V_{m}=3.45(1010-M S L P)^{0.644}
$$

ここに, $V_{m}$ : 最大風速 $(\mathrm{m} / \mathrm{s}), M S L P$ : 最低海面更正気 圧 $(\mathrm{hPa})$ である.

\section{2)＼cjkstart海洋モデルの FVCOM の設定}

海面抵抗係数に本多・光易の式 ${ }^{17)}$ に横田ら ${ }^{18)}$ の風速 30 $\mathrm{m} / \mathrm{s}$ 以上は一定となるとの条件を加えた式 (2) を用いた.

$$
\begin{gathered}
C_{D}=\left(1-0.01890 \times W_{s}\right) \times 0.00128\left(W_{s} \leq 8 \mathrm{~m} / \mathrm{s}\right) \\
C_{D}=\left(1+0.1078 \times W_{s}\right) \times 0.000581 \\
\left(8 \mathrm{~m} / \mathrm{s} \leq W_{s} \leq 30 \mathrm{~m} / \mathrm{s}\right) \\
C_{D}=0.00246\left(W_{s} \geq 30 \mathrm{~m} / \mathrm{s}\right)
\end{gathered}
$$

ここに, $C_{D}$ : 海面抵抗係数, $W_{s}$ : 風速 $(\mathrm{m} / \mathrm{s})$ である. 海底地形には GEBCO_08 $\left.{ }^{19}\right)$ を使用した。海岸線は SRTM 90 monを使用した。図-5 は，FVCOM で使用した

\begin{tabular}{|c|c|c|}
\hline & 項目 & 内容 \\
\hline \multirow{8}{*}{$\begin{array}{l}\text { W } \\
\text { R } \\
\text { F }\end{array}$} & 計算期間 (fnl-1, gfs-1) & 2014年12月16日21:00－2014年12月18日 03:00 (JST) \\
\hline & 計算期間（fnl-2, gfs-2) & 2014年12月 17日03:00－2014年12月18日 03:00 (JST) \\
\hline & ドメイン1 (grids, range, mesh) & 120x120, WE: $133.8^{\circ}-152.2^{\circ}, \mathrm{SN}: 34.8^{\circ}-48.5^{\circ}, 15 \mathrm{~km}$ \\
\hline & ドメイン2 (grids, range, mesh) & $201 \times 221, \mathrm{WE}: 142.9^{\circ}-149.1^{\circ}, \mathrm{SN}: 41.0^{\circ}-46.0^{\circ}, 3 \mathrm{~km}$ \\
\hline & 鉛直層及ひ頂点気压 & 36 layers and $2000 \mathrm{~Pa}$ \\
\hline & 雲微物理スキーム & WSM $6^{14)}$ \\
\hline & 積雲対流スキーム & Kain-Fritsch $^{15)}$ \\
\hline & 投影法 & Mercator \\
\hline \multirow{4}{*}{$\begin{array}{l}\mathrm{TC} \\
\text { ボー } \\
\text { ガス }\end{array}$} & 埋め込み期間 & 2014年12月 16日21:00－2014年12月18日 03:00 (JST) \\
\hline & ドメイン (grids, range, mesh) & $400 \times 400, \mathrm{EW}: 137.8^{\circ}-150.2^{\circ}, \mathrm{SN}: 34.9^{\circ}-46.6^{\circ}, 3 \mathrm{~km}$ \\
\hline & 鉛直層及び頂点気圧 & 36 layers and $2000 \mathrm{~Pa}$ \\
\hline & 最大風速半径 & $50 \mathrm{~km}, 60 \mathrm{~km}, 70 \mathrm{~km}, 80 \mathrm{~km}, 90 \mathrm{~km}, 100 \mathrm{~km}$ \\
\hline \multirow{5}{*}{$\begin{array}{l}\mathrm{F} \\
\mathrm{V} \\
\mathrm{C} \\
\mathrm{O} \\
\mathrm{M}\end{array}$} & 計算時間 & 各ケースのWRFの計算時間と同一 \\
\hline & 計算範囲 & EW: $144.2^{\circ}-146.7^{\circ}, \mathrm{SN}: 42.3^{\circ}-45.1^{\circ}$ \\
\hline & Cell & 114782 \\
\hline & Node & 58594 \\
\hline & $\sigma$ vertical layer & 11 \\
\hline
\end{tabular}
非構造格子の地形の一部である. 根室付近の最小の格子 幅は約 $100 \mathrm{~m}$ と設定した. 非構造格子を使用すると根室 半島の複雑な地形に沿った海岸線を作成できる（図-5).
表-2 計算条件の設定

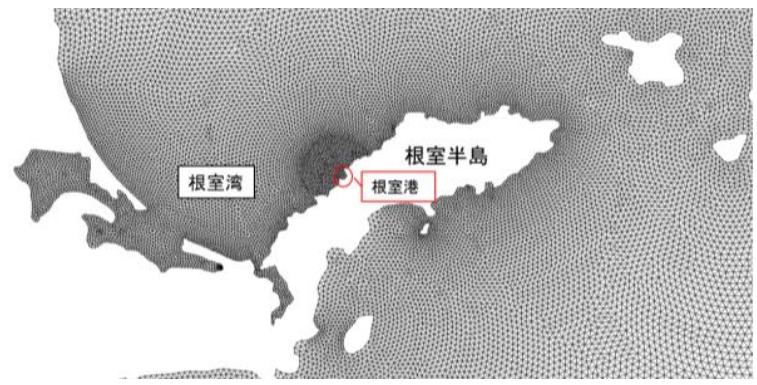

図-5 根室周辺における非構造格子の地形の一部

\section{5. 算定結果と考察}

\section{1) 気象モデルの計算結果}

a) 根室市弥栄町における風速の比較

図-6は, 弥栄町における風速の算定結果と観測值の比 較である. 17 日 5 時と 9 時に風速の観測值は $25 \mathrm{~m} / \mathrm{s}$ を超 えている. ここで, FNL と GFS の各ケースの風速計算 結果は，観測值とよく一致している. 特に，17 日 5 時か ら9時における風速の急激な変化を算定している. 一方 で，TC ボーガスのケースでは，低気圧の中心が根室を 通っていないため，風速の急激な変化を算定していない が，TC-60の全体的な風速值は観測值に近かった。最大 風速半径を増大させると観測值との差異も増加した.

\section{b) 根室市弥栄町における風向の比較}

表-3 では, 弥栄町における計算結果と観測值の風向を 比較している（紙面の都合上，各ケースの平均風向を掲 載)。FNLと GFS の各ケースでは，午前 8 時以降には 西南西の風に変化しており，観測值の風向と合致してい ない.一方で, TC ボーガスを用いた場合の風向は午前 8 時，9 時は，北北西，北西であり，観測值と比較して若 干の差異はあるものの, よく一致している.

\section{c) 根室市弥栄町における海面更正気圧の比較}

図-7は，弥栄町における，海面更正気圧の算定值と観 測值である．観測值は，17 日 8 時に 950hPa まで低下し ている．この時間には温帯低気圧の中心気圧が $948 \mathrm{hPa}$ 


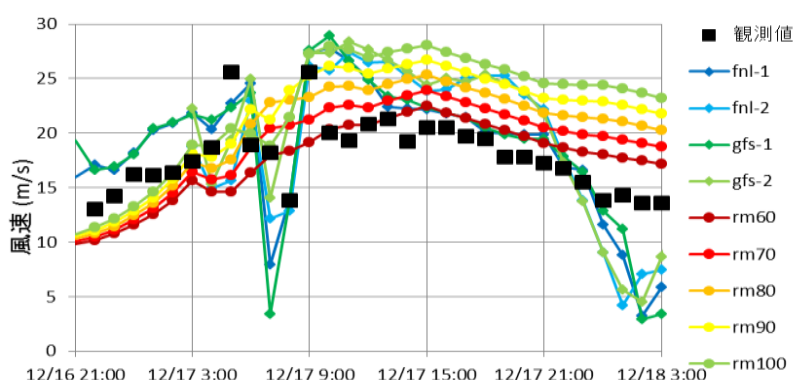

図-6＼cjkstart根室市の観測所における風速の比較

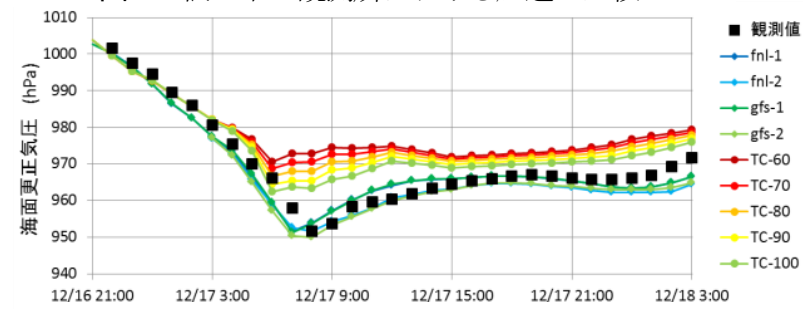

図-7＼cjkstart根室市の観測所における海面更正気圧の比較

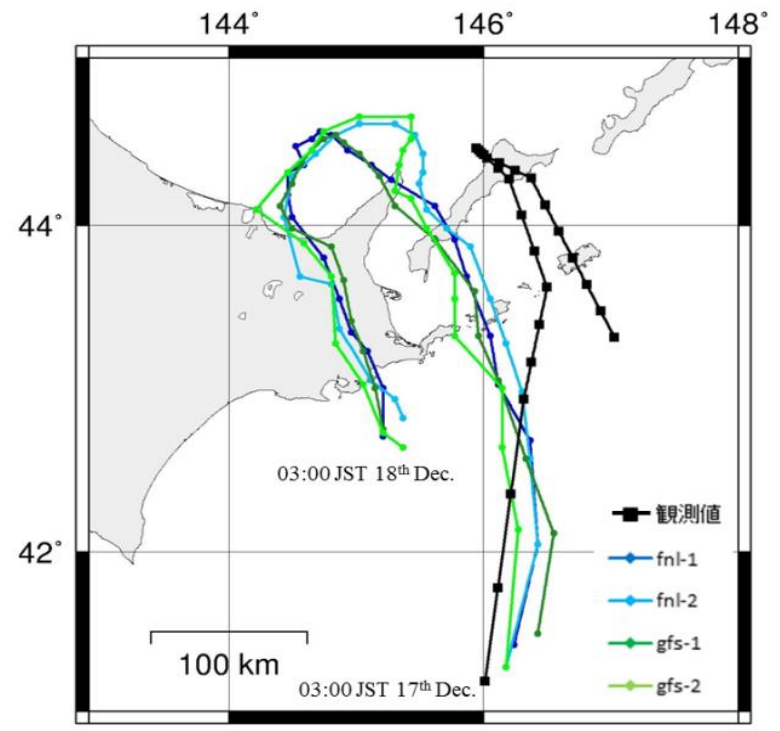

図-8 低気圧の中心位置の比較

表-3 根室市の観測所における風向の比較

\begin{tabular}{|l|l|l|r|r|r|r|r|r|r|r|}
\hline $2014 / 12 / 17$ & $3: 00$ & $4: 00$ & $5: 00$ & $6: 00$ & $7: 00$ & $8: 00$ & $9: 00$ & $10: 00$ & $11: 00$ & $12: 00$ \\
\hline 観測値 & 東 & 東 & 東 & 北北東 & 北北東 & 北 & 西北西 & 西 & 西南西 & 西南西 \\
\hline FNLとGFSの平均值 東 & 東 & 東北東 & 北東 & 北東 & 西南西 & 西南西 & 西南西 & 西南西西南西 \\
\hline TCケースの平均值 & 東 & 東北東 & 北北東 & 北 & 北北西 & 北西 & 西北西 & 西北西 & 西 \\
\hline
\end{tabular}

であるため, 気圧の中心位置を考慮すると, 低気圧の 950 $\mathrm{hPa}$ 以下の範囲が約 $80 \mathrm{~km}$ 広がっていた可能性がある.

FNL と GFS を用いた 4 ケースは，観測值とよく一致し ている，これは，根室の上空を低気圧が通過したためで ある。一方で， TC ボーガスを用いたケースは，最大風 速半径が $60 \mathrm{~km}$ の場合に，20 hPa 程の差異がある．最大 風速半径を広げていくにつれて, 差異は減少したが, 100 $\mathrm{km}$ の場合においても $10 \mathrm{hPa}$ 程の差異となっている.

\section{d) 低気圧の経路の比較}

図-8 は低気圧の中心位置の 17 日午前 3 時以降の 1 時 間毎の時間変化である. 気象庁の速報值から求めた低気 圧の中心を観測值として表示している．TC ボーガスを 用いた各ケースは，観測值を基に低気圧を埋め込んでい るため，その経路は気象庁の観測值と同一となる．FNL と GFS を用いて計算した低気圧は，17日 6 時頃まで観 測值の経路とよく一致しているが，観測よりも早い時間 に根室付近を通り過ぎている，これが，風向の変化が観 測值よりも早い時間に変化した原因である．急速発達す る低気圧の詳細な再現は難しく，観測值の経路との差異 は高潮の算定精度に影響を及ぼす可能性が高い.

\section{e) 各ケースの気象場の評価}

FNL と GFS を用いたケースでは，気圧と風速の急速 な変化を算定しているが，高潮が発生した午前 8 時から 9 時の風向を精度よく算定していない. これが高潮偏差 の算定精度に影響を与える可能性がある. TC ボーガス のケースは，TC ボーガスが低気圧の構造を詳細に再現 できず，速報值に誤差があるためと考えられるため，風 速の急激な变化と気圧は精度よく算定できておらず，気 圧の差異を考えると最大風速半径の厳密な決定は難しい が，風速・風向の全体的な傾向は TC60 が観測值とよく
合致している，更に，低気圧の算定精度を改善するため には，JMA-MSM の使用，低気圧の中心位置の誤差の考 慮， TC ボーガスの改良や経験式の使用などの方法が考 えられる.これらについては今後の課題としたい.

\section{2) 海洋モデルによる高潮の算定結果}

図-9 は根室港における高潮偏差の比較である. 北海道 開発局所管施設の根室における観測值 ${ }^{7)}$ と計測地点 $\mathrm{K}, \mathrm{J}$ の值は，天文潮位を除いた高潮偏差へ補正している.

a) GFS と FNL を用いたケース

GFS と FNLの 4 ケースでは, 最大高潮偏差が $0.5 \sim 0.6$ $\mathrm{m}$ 程度に留まっている. この值は，観測值と $1.2 \sim 1.3 \mathrm{~m}$ 程の差異がある. 計算開始時の水位は観測值と比較して, 約 0.4 m (fnl-1, gfs-1), 約 0.6 m (fnl-2, gfs-2) と低い. この差異を考慮しても，GFS と FNLの 4 ケースでは約 $0.6 \mathrm{~m}$ から $0.9 \mathrm{~m}$ 過小評価している.これは, GFS と FNL の 4 ケースにおいて，(1)高潮が発生した午前 8 時から 9 時の風向を精度よく算定していないため，(2)根室港では 風速值は観測值近いが，根室湾から太平洋側にかけての 海上で，低気圧による風速の全体的な強度を過小評価し た，という2つの理由が考えられる，(1)につては，時

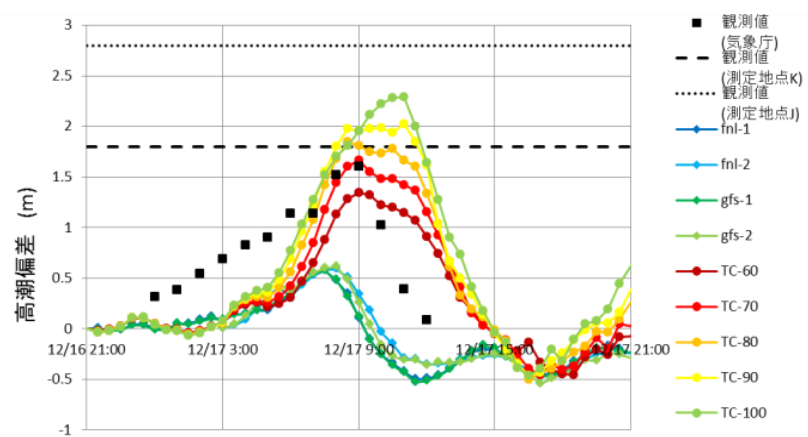

図-9＼cjkstart根室港における高潮偏差の比較 


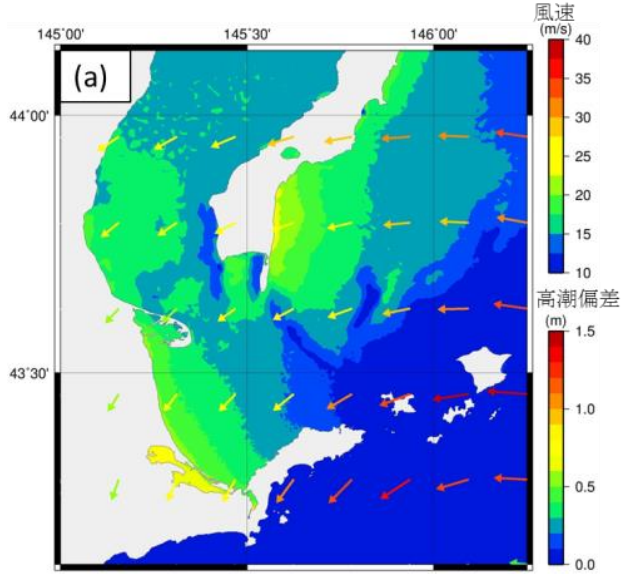

図-10 TC-60 の根室周辺の高潮偏差と風速（矢印の色が風速を示す）（a） 17 日 6 時 00 分， (b) 17 日 9 時 00 分 系列全体の風向の観測值との差異に加えて，最高偏差を 観測した 17 日午前 8 時から 9 時における風向が南西より に変化している．そのため，午前 8 時以降は，根室港の 高潮偏差が上昇しきらず，過小評価したと考えられる. 実際に，いずれのケースでも午前 7 時に高潮偏差は最高 值となっており，上記と符合している。また, FNL, GFS を用いた WRF の計算は，風や気圧を過小評価する傾向 があるという報告もあり ${ }^{8)}$ ，(2)の理由を裏付けている.

\section{b) TC ボーガスを用いたケース}

TC ボーガスを用いたケースでは，最大風速半径が 60, 70, 80, 90, $100 \mathrm{~km}$ の各ケースで，高潮偏差は 1.3, 1.7, $1.9 ， 2.0,2.3 \mathrm{~m}$ となっている (図-9). 計算開始時の約 $0.4 \mathrm{~m}$ の水位上昇を考慮すると, TC-60 の高潮偏差が観測 值に近い值となる．これは，風速・風向の算定值と観測 值が，面的・時系列的に一致していたためと考えられる

(図-6，表-3)。また，気象庁の観測值と比較して，高 潮偏差の立ち上がりが遅く，ピーク值のみ観測值と合致 している結果になっている. 本研究では，高潮算定に波 浪の効果を考慮していない. 波浪の計算を行い外洋から の波の侵入を考慮することでより詳細に再現できると考 えられる. また, 午前 9 時以降の急激な風向変化に伴う 高潮偏差の急激な減少は, 全てのケースで午前 12 時以降 となっている.これは, 午後 12 時以降に根室の風が西風 になったからである. 算定された気象場の改善を行うこ とで,より精度よく高潮を再現することが可能であろう。

\section{c) 根室において生じた高潮の発生機構}

初期水位の $0.4 \mathrm{~m}$ を考慮した場合の高潮偏差の傾向と 值が最も観測值に近かった TC-60の高潮偏差の結果を図 -10 に示す. 図-10 (a) 17 日 6 時と（b）17日9時の高 潮偏差と風速風向を示した図である. 図より午前 6 時の 時点で高潮偏差の上昇が既に始まっており, 午前 9 時に は，根室半島周辺北側の海岸線で高潮偏差が上昇してい る結果となった。 まず，東風が吹き，根室湾内の水位が 上昇する. 次に, 低気圧の移動に伴い, 徐々に北風に変 化して, 根室半島の周辺の高潮偏差が上昇し, 高潮被害 が生じたと考えた.この結果は, 時間的な差異はあるが,

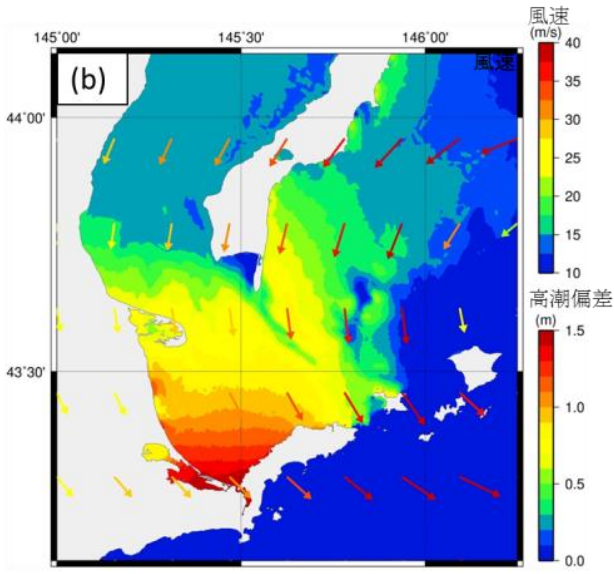

TC-60 の根室の風速・風向の観測值との全般的な一致を 考慮すると，概ね発生機構を捉えていると考えられる.

\section{6. 結論}

本研究では，根室市で生じた高潮の現地調査と数值解 析の結果を示した．現地調査の結果，被害が生じた地域 では, 地盤高が海岸から市街地に向かって低下していた。 また, 数值解析の結果から, まず東風が吹き，根室湾の 水位が上昇し, 次に, 東風が北風に変化して, 根室湾に 溜まった水塊が根室半島に吹き寄せて, 根室港で高潮偏 差が上昇したことが解った. 今回の高潮被害は以上のよ うな複数の要因が重なり生じた可能性が指摘できる。根 室市街地と根室港は，高潮の影響を受けやすい場所であ り，対策が必要である．最後に，低気圧の再現精度をよ り高めるために, JMA-MSM の使用, TC ボーガス手法 の改良や経験式の構築が必要である。また，波浪の効果 も検討することで，より詳細に根室で生じた高潮を解明 することができる.これらは今後の課題としたい.

謝辞 : 本研究は私立大学戦略的基盤形成支援事業「減災 研究の国際展開のための災害研究基盤の形成」,科学研究 費補助金基盤(B)No.22404011（ともに，代表者 : 柴山知 也）のもとに行われた. 観測当時, 早稲田大学社会環境 工学科 4 年の金暉氏に現地調査を補佐して頂いた. 記し て謝意を表する

\section{参考文献}

1) IPCC : Summary for Policymakers. In: Climate Change 2013: The Physical Science Basis. Contribution of Working Group I to the Fifth Assessment Report of the Inter-governmental Panel on Climate Change [Stocker et al]. Cambridge University Press, Cambridge, United Kingdom and New York, NY, USA. 2013. 
2) 吉野純，村上智一，林雅典，安田孝志 : 高潮計算精 度に及ぼす入力台風気象場の再現性の影響, 海岸工 学論文集，第 53 巻，pp.1276-1280，2005.

3）森信人，高木友典，川口浩二，加島寛章，間瀬 肇, 安田誠宏, 島田広昭: 2012 年 4 月 3 4 日 に日本海で急発達した低気圧による暴波浪特性, 土木学会論文集 B2 海岸工学, Vol.69, pp.126-130, 2013.

4) 気象庁 : 2014/2015 年冬の大気循環場の特徵につい て, pp.41, [http://www.data.jma.go.jp/gmd/extreme/ kaigi/2015/0223_teirei/h26gidai3.pdf], 2015. 参照 2015-04-27.

5) 気象庁: 気象速報, 平成 26 年 12 月 $16 \sim 18$ 日の 暴風雪、高波、高潮に関する気象速報（釧路・ 根室地方）第 1 報 [http://www.jma-net.go.jp/kushro/tenki/sokuhou/pdf/sokuhou20141216-1218_1.p df], 2014. 参照 2015-03-12.

6) Sunny Spot : SPAS 速報天気図. [http://www.sunnyspot.net/chart], 2015. 参照 2015-02-07.

7) 気象庁: 平成 26 年 12 月 17 日に発生した、 急速に発達した低気圧による根室地方の高潮に 関する現地調查報告（第 2 報 (最終報)) [http://www.jma-net.go.jp/sapporo/oshirase/2015/sp _press150116_kushiro.pdf], 2015.参照 2015-04-28.

8) 中村亮太，大山剛弘，柴山知也，松丸亮，高木 泰士, Miguel ESTEBAN，三上貴仁：Typhoon Yolanda によるフィリピンの高潮被災の高潮追 算と現地調査の比較, 土木学会論文集 B2 海岸 工学，第 70 巻, No. 2, pp. I_236-I_240, 2014.

9) Skamarock., W. C., Klemp, J. B., Dudhia, J., Gill, D. O., Barker, D. M., Duda, M. G., Huang, X. Y., Wang, W. and Power, J. G. : A Description of the Advanced Research WRF Version 3. NCAR TECHNICAL NOTE, 2008.

10) Chen C., Liu, H. and Beardsley R. C. : An unstructured, finite-volume, three-dimensional primitive equation ocean model: application to coastal ocean and estuaries, Journal of Atmospheric and OceanicTechnology, Vol. 20, pp. 159-186, 2003.

11) NCAR : NCEP FNL Operational Model Global 2014. Tropospheric Analyses, continuing from July 1999, [http://rda.ucar.edu/datasets/ds083.2 /]. 参照 2015-01-10.

12) NCAR : Historical Unidata Internet Data Distribution (IDD) Gridded Model Data, December 2002 - current [http://rda.ucar.edu/datasets/ ds335.0]，2014. 参 照 2015-01-10.

13) Davis, C. and Low - Nam. S. : The NCAR - AFWA tropical cyclone bogussing scheme, report, $21 \mathrm{pp}$., U.S. Air Force Weather Agency, Offutt, AFB, Nebr. 2001.

14) Hong, S. Y. and Lim, J. O. J. : The WRF singlemoment 6-class microphysics scheme (WSM6). Journal of Korean Meteorological Society Vol. 42, pp.129-151. 2006.

15) Kain, J. S. : The Kain-Fritsch convective parameterization: An update. Journal of Applied Meteorology and Climatology Vol.43, pp.170-181, 2004.

16) Atkinson, G. D. and Holliday, C. R. : Tropical cyclone minimum sea level pressure/maximum sustained wind relationship for the western North Pacific, Mon. Wea. Rev., Vol.105, pp.421-427, 1977.

17) 本多忠夫，光易恒：水面に及ぼす風の作用に関 する実験的研究, 海岸工学論文集, Vol. 27, pp.90-93, 1980.

18）横田雅紀，橋本典明，田中雄太，児玉充由：うねり を観測する条件での海面抵抗係数の逆推定精度に関 する検討, 土木学会論文集 B3 海洋開発, Vol.67, No.2. pp.903-907, 2011.

19) GEBCO : [http://www.gebco.net/], 2014. 参 照 2015-01-07.

20) CGIARCSI : [http://www.cgiar-csi.org/data/srtm-90m-dig ital-elevation-database-v4-1], 2014. 参照 2014-12-25.

Field survey and mechanism of storm surge generation invoked by the low pressure with rapid development in Nemuro Hokkaido in December 2014

\section{Ryota NAKAMURA, Takumu IWAMOTO, Tomoya SHIBAYAMA, Takahito MIKA- MI, Shunya MATSUBA, Martin MAELL, Akihumi, TAKEKOUJI and Yusuke TANOKURA}

The low pressure with rapid development generated storm surge and inundation over a port and city in Nemuro. The aims of this paper are to provide the information of storm surge height measured by the authors and to clarify the generation mechanism of the storm surge. Based on the authors' field survey, the maximum storm surge height at the street and the port in Nemuro was approximately $2.20 \mathrm{~m}$ and 2.80 $\mathrm{m}$, respectively. Furthermore, the ground level in Nemuro decreased from coastal line toward the street. According to the numerical results with WRF and FVCOM, the water level in Nemuro bay increased at first because of the East wind. Then, the mass of water intrudes to the Nemuro Peninsula because of north wind and caused the storm surge. In conclusion, the local topography of Nemuro, the direction changes of wind and the topography of Nemuro Peninsula caused the damage of the storm surge to Nemuro. 